\title{
X-Ray, DSC, TGA-dTGA, and Vibrational Studies of the Propylenediammonium Hexafluorosilicate $\mathrm{NH}_{3}\left(\mathrm{CH}_{2}\right)_{3} \mathrm{NH}_{3} \mathrm{SiF}_{6}$
}

\author{
Ali Ouasri 1,2,* (D), Ali Rhandour ${ }^{1}$, Mohammed Saadi ${ }^{3}$ (D), Lahcen El Ammari ${ }^{3}$ (D) \\ 1 Laboratoire de Physico-Chimie des Matériaux Inorganiques, Faculty of Sciences, Ibn Tofaïl University, BO 133, 14000 \\ Kenitra, Morocco \\ 2 Laboratoire (ReSIP), Centre Régional des Métiers de l'Education et de la Formation, Madinat Al Irfane, Souissi, BP 6210 \\ Rabat, Morocco \\ 3 Laboratoire de Chimie Appliquée des Matériaux, Centre des Sciences des Matériaux, Faculty of Sciences, Mohammed V \\ University in Rabat, Avenue Ibn Batouta, B.P. 1014, Rabat, Morocco \\ * Correspondence: aouasri@yahoo.fr;
}

Scopus Author ID 56001570100

Received: 15.12.2020; Revised: 20.01.2021; Accepted: 23.01.2021; Published: 31.01.2021

\begin{abstract}
X-ray characterization, thermal behavior, and vibrational studies have been performed on $\mathrm{NH}_{3}\left(\mathrm{CH}_{2}\right)_{3} \mathrm{NH}_{3} \mathrm{SiF}_{6}$, which crystallized in the $\mathrm{P} 2_{1} / \mathrm{c}(\mathrm{Z}=4)$ monoclinic system. The $\mathrm{V} / \mathrm{Z}$ ratio variation (unit cell volume/ motifs number per cell) versus the $\mathrm{CH}_{2}$ groups' number is discussed for $\mathrm{H}_{3} \mathrm{~N}\left(\mathrm{CH}_{2}\right)_{\mathrm{n}} \mathrm{NH}_{3} \mathrm{SiF}_{6}$ salts $(\mathrm{n}=2,3,4,6)$. The DSC measurements (heating/cooling) recorded in the 35$245^{\circ} \mathrm{C}$ temperature domain showed the $\mathrm{NH}_{3}\left(\mathrm{CH}_{2}\right)_{3} \mathrm{NH}_{3} \mathrm{SiF}_{6}$ decomposition above $30{ }^{\circ} \mathrm{C}$, which is checked and analyzed by TGA-dTGA techniques. The vibrational spectra interpretation is developed based on theoretical group analyses considering the ${ }^{+} \mathrm{NH}_{3}\left(\mathrm{CH}_{2}\right)_{3} \mathrm{NH}_{3}{ }^{+}$cations and the $\mathrm{SiF}_{6}{ }^{2-}$ anions in the $\mathrm{C}_{1}(4)$ and $\mathrm{C}_{\mathrm{i}}(2)$ symmetry sites, respectively. The $\mathrm{SiF}_{6}{ }^{2-}$ degenerated modes splitting is explained by the site effect, resulting in symmetry lowering from $\mathrm{O}_{\mathrm{h}}$ to $\mathrm{C}_{\mathrm{i}}$ in the crystal. The Infrared spectrum analysis at lower $\mathrm{N}-\mathrm{H}$ and $\mathrm{C}-\mathrm{H}$ frequencies region showed the presence of medium to strong $\mathrm{N}-\mathrm{H} \cdots \mathrm{F}$ hydrogen bonding in the title compound.
\end{abstract}

Keywords: propylenediammonium; hexafluorosilicate; X-ray; DSC; TGA-dTG; IR; Raman; decomposition; site group; factor group.

(C) 2021 by the authors. This article is an open-access article distributed under the terms and conditions of the Creative Commons Attribution (CC BY) license (https://creativecommons.org/licenses/by/4.0/).

\section{Introduction}

Hexafluorosilicate compounds of the general formula [ $\left.\mathrm{R}_{4-n} \mathrm{NH}_{\mathrm{n}}\right]_{2} \mathrm{SiF}_{6}(\mathrm{R}$ : alkyl, $\mathrm{n}=0$, $1,2,3)$ studied over the two last decades [1-16] have been found to present interesting crystal dynamic and phase transitions involving as well as hydrogen bonds and reorientation motions of alkylammoniums cations [1-8]. The temperature-dependent phase transitions in such compounds have been studied using differential scanning calorimetry (DSC), Raman spectroscopy at different temperatures, and optical properties.

The crystal structures, the physicochemical properties, and the anticaries activities of novel potential anticaries hexafluorosilicate substances are developed [14-22]. The pyridinium hexafluorosilicate salts $(\mathrm{LH})_{2} \mathrm{SiF}_{6}(\mathrm{~L}=2-, 3-$, 4-carboxymethylpyridine) with the general formula $\left(\mathrm{C}_{14} \mathrm{H}_{16} \mathrm{~N}_{2} \mathrm{O}_{4}\right)_{2} \mathrm{SiF}_{6}$ crystallized in the ( $\left.\mathrm{P} 2{ }_{1} / \mathrm{n}, \mathrm{Z}=2\right),\left(\mathrm{P}{ }_{1} / \mathrm{c}, \mathrm{Z}=2\right)$, and $(\mathrm{I} 2 / \mathrm{a}, \mathrm{Z}=4)$, respectively [15]. Gelmboldt et al. [16] have developed a review study, summarizing the research results published mainly after 2000 on the synthetic protocols, structure, spectral 
characteristics, solubility and hydrolysis, properties, and the practical application aspects of the hexafluorosilicate salts. This study reflected various aspects of the state of chemistry and applied use of hexafluorosilicate salts obtained up 2019: modifiers of zeolite catalysts, fluoridating agents, activating additives and catalysts, preparation of amorphous silica, ionic liquids, and electro-optical materials.

The biological activity analysis showed a low probability of toxic effects of the novel hexafluorosilicate $(\mathrm{LH})_{2} \mathrm{SiF}_{6} \cdot \mathrm{H}_{2} \mathrm{O} \quad$ (L: 3-hydroxymethylpyridine) compound [17]. Hexafluorosilicate salts with the substituted pyridinium and pyrimidinium cations exhibit antibacterial, anti-inflammatory, and other activity types, which leads to an experimentally confirmed increase in cariesprophylactic efficacy (CPE) of such substances compared to reference drugs [18]. It has been demonstrated that ammonium hexafluorosilicates, including salts with substituted biologically active ammonium cations, have a high cariesprophylactic efficacy $[20,21]$.

The hexafluorosilicate $\mathrm{NH}_{3}\left(\mathrm{CH}_{2}\right)_{n} \mathrm{NH}_{3} \mathrm{SiF}_{6}$ compounds, belonging to the alkylenediammonium hexalogenometallate salts family $\mathrm{NH}_{3}\left(\mathrm{CH}_{2}\right)_{n} \mathrm{NH}_{3} \mathrm{MX}_{6}(\mathrm{M}: \mathrm{Sn}, \mathrm{Si} ; \mathrm{X}: \mathrm{Cl}$, F) [23-31], are recently found to present interesting properties in catalysis [13-16, 23-30]. Research including X-ray diffraction, thermal, vibrational, and phase transitions studies have also been reported on alkylenediammonium chlorobismuthate salts $\left[\mathrm{NH}_{3}\left(\mathrm{CH}_{2}\right)_{12} \mathrm{NH}_{3}\right]_{2} \mathrm{BiCl}_{6} . \mathrm{Cl} .2 \mathrm{H}_{2} \mathrm{O}$ [32] and $\mathrm{NH}_{3}\left(\mathrm{CH}_{2}\right)_{n} \mathrm{NH}_{3} \mathrm{BiCl}_{5}$ [33-40].

The $\mathrm{NH}_{3}\left(\mathrm{CH}_{2}\right)_{2} \mathrm{NH}_{3} \mathrm{SiF}_{6}$, monoclinic of space group $\mathrm{P}_{2} / \mathrm{n}(\mathrm{Z}=2)$, is the first compound studied among the alkylenediammonium hexafluorosilicate salts [25]. Its structure consisted of $\mathrm{SiF}_{6}{ }^{2-}$ octahedra located on the inversion centres of the Wyckoff positions [2d $(1 / 2,1 / 2,0) ; 2 \mathrm{c}$ $(0,0,1 / 2)]$, and ethylendiammonium cations also placed on inversion centers $[2 \mathrm{a}(0,0,0) ; 2 \mathrm{~b}$ $(1 / 2,1 / 2,1 / 2)]$. The ${ }^{+} \mathrm{NH}_{3}\left(\mathrm{CH}_{2}\right)_{2} \mathrm{NH}_{3}{ }^{+}$cations and $\mathrm{SiF}_{6}{ }^{2-}$ anions are linked with $\mathrm{N}-\mathrm{H} \cdots \mathrm{F}$ hydrogen bonding, ensuring the three-dimensional cohesion of the crystal.

More recently, works reporting crystal structures, vibrational studies, DFT modeling, and catalysis have been made on two alkylenediammonium hexafluorosilicate compounds $\mathrm{NH}_{3}\left(\mathrm{CH}_{2}\right)_{n} \mathrm{NH}_{3} \mathrm{SiF}_{6}(\mathrm{n}=4,6)$ [26-30]. The crystal structure of $\mathrm{NH}_{3}\left(\mathrm{CH}_{2}\right)_{4} \mathrm{NH}_{3} \mathrm{SiF}_{6} P-1(\mathrm{Z}=1)$ consisted of the $\mathrm{SiF}_{6}{ }^{2-}$ anion observed on an inversion center $\mathrm{C}_{\mathrm{i}}(1)$ compatible to the Wyckoff the position $1 \mathrm{~d}(1 / 2,0,0)$, the bond $\mathrm{C} 2-\mathrm{C} 2 \mathrm{i}$ center of the cation is placed on another inversion center [26]. The structure of $\mathrm{NH}_{3}\left(\mathrm{CH}_{2}\right)_{6} \mathrm{NH}_{3} \mathrm{SiF}_{6} P-1(\mathrm{Z}=2)$, is built up from two $\mathrm{SiF}_{6}{ }^{2-}$ anions and two organic cations ${ }^{+} \mathrm{NH}_{3}\left(\mathrm{CH}_{2}\right)_{6} \mathrm{NH}_{3}{ }^{+}$[25]. An anion $\mathrm{Si1}$ is observed in the general position $(\mathrm{x}, \mathrm{y}, \mathrm{z})$ of $\mathrm{C}_{1}$ symmetry. The two moieties of anions are located at inversion centers: $\mathrm{Si} 2$ on the Wyckoff position $1 \mathrm{~g}(0,1 / 2,1 / 2)$ and $\mathrm{Si} 3$ on $1 \mathrm{a}(0,0,0)$. The unit cell contains one organic cation and two halves of cations located at inversion centers.

The hexafluorosilicate $\mathrm{NH}_{3}\left(\mathrm{CH}_{2}\right)_{n} \mathrm{NH}_{3} \mathrm{SiF}_{6}$ structure is monoclinic of space group $\mathrm{P} 21 / \mathrm{n}$ for $(\mathrm{n}=2)$, triclinic of space group $P-1(\mathrm{Z}=1)$ when $\mathrm{n}=4$, and $P-1(\mathrm{Z}=2)$ for $\mathrm{n}=6$. In the $\mathrm{P} 2{ }_{1} / \mathrm{n}$ space group, there are 4 sets of non-equivalent inversion centers $4 \mathrm{C}_{\mathrm{i}}(2)$, while in the $P-1$ there are 8 non-equivalent inversion centers $8 \mathrm{C}_{\mathrm{i}}(1)$. In the $\mathrm{NH}_{3}\left(\mathrm{CH}_{2}\right)_{n} \mathrm{NH}_{3} \mathrm{SiF}_{6}$ structures, the

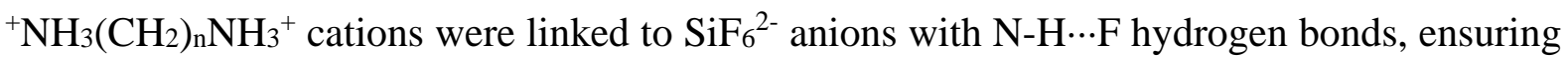
the three-dimensional cohesion of the crystals.

In this work, we present X-ray, DSC, TGA-dTGA, Infrared, and Raman spectra studies carried out on $\mathrm{NH}_{3}\left(\mathrm{CH}_{2}\right)_{3} \mathrm{NH}_{3} \mathrm{SiF}_{6}$. The vibrational spectroscopy aiming to support the compound structural characterization by extracting the structure-spectra correlations is a powerful tool to describe the cations' behavior and their contribution to the distortion of the 
$\mathrm{SiF}_{6}{ }^{2-}$ octahedral structure. The free ions symmetry changed in the crystal structure, which influences the infrared and Raman bands' vibrational selection rules and assignment.

\section{Materials and Methods}

$\mathrm{NH}_{3}\left(\mathrm{CH}_{2}\right)_{3} \mathrm{NH}_{3} \mathrm{SiF}_{6}$ crystals were obtained by slow evaporation at room temperature of an aqueous solution containing stoichiometric amounts of alkylenediamine $\mathrm{NH}_{2}\left(\mathrm{CH}_{2}\right)_{3} \mathrm{NH}_{2}$ and $\mathrm{H}_{2} \mathrm{SiF}_{6}$ acid, following the chemical reaction, described as:

$$
\mathrm{NH}_{2}\left(\mathrm{CH}_{2}\right)_{3} \mathrm{NH}_{2}+\mathrm{H}_{2} \mathrm{SiF}_{6} \rightarrow \mathrm{NH}_{3}\left(\mathrm{CH}_{2}\right)_{3} \mathrm{NH}_{3} \mathrm{SiF}_{6}
$$

A single crystal is carefully selected using a polarizing microscope. Data are collected at room temperature using the Bruker Apex2 AXS X8 diffractometer equipped with a CCD detector and a graphite monochromator for Mo Ka radiation $(\mathrm{k}=0.71073 \AA)$.

The powder of $\mathrm{NH}_{3}\left(\mathrm{CH}_{2}\right)_{3} \mathrm{NH}_{3} \mathrm{SiF}_{6}$ compound is characterized at room temperature by the X-ray diffraction method using an XRD-XPERT PRO-Panalytical performed with BraggBrentano geometry and $\mathrm{CuK} \alpha$ radiation. $(\lambda=1.5418 \mathrm{~A})$. The XRD pattern is performed in the range of $2 \theta$ between $10^{\circ}$ and $90^{\circ}$ with $40 \mathrm{kV}$ and $50 \mathrm{~mA}$ operating conditions.

The differential scanning calorimetric measurements were performed on the powdered compound in a DSC-Q100 calorimeter (from TA Instruments) using sample masses $6.39 \mathrm{mg}$ in a hermetic aluminum sample holder, from $45^{\circ} \mathrm{C}$ to $245^{\circ} \mathrm{C}$ at a heating and cooling rate of $5^{\circ} \mathrm{C} \mathrm{m^{-1 }}$ under nitrogen atmosphere, flowing at $50 \mathrm{~mL} \mathrm{~min}^{-1}$.

The thermogravimetric analyses (TGA-dTGA) of the compound have been performed with a TA Instruments balance model STA-1640. It allows for obtaining simultaneous TGA and dTGA diagrams under similar experimental conditions. Experiments were performed under a nitrogen atmosphere, from $30^{\circ} \mathrm{C}$ to $245^{\circ} \mathrm{C}$ at a heating rate of $5^{\circ} \mathrm{C} / \mathrm{min}$. About 12.683 $\mathrm{mg}$ of the compound was used initially for these measurements.

The Infrared spectrum was recorded in the $450-4000 \mathrm{~cm}^{-1}$ spectral range with a $4 \mathrm{~cm}^{-1}$ resolution (64 scans), by using a VERTEX 70 FTIR spectrometer (produced by BRUKER Optics). The crystals were ground in a clean mortar to a fine powder. The MIR Transmission Technic was used to record the IR spectrum.

The Raman spectra were recorded at room temperatures, in the $25-3500 \mathrm{~cm}^{-1}$ by using a RAM spectrometer (220 mw) coupled with the VERTEX 70, and equipped with the exciting source Laser of a radiation wavelength $(455 \mathrm{~nm})$ and a puissance laser of $6.0 \mathrm{mw}$.

\section{Results and Discussion}

\subsection{X-ray characterization.}

The single crystal X-Ray diffraction characterization carried out on $\mathrm{NH}_{3}\left(\mathrm{CH}_{2}\right)_{3} \mathrm{NH}_{3} \mathrm{SiF}_{6}$ at ambient temperature showed that the title compound crystallizes in the monoclinic system with $P 2{ }_{1} / \mathrm{c}(\mathrm{Z}=4)$ as space group $[\mathrm{a}=18.871(4) \AA, \mathrm{b}=5.879(2) \AA, \mathrm{c}=$ 17.345(3) $\left.\AA ; \beta=117.331(3), V=1709.44 \AA^{3}\right]$. The full crystal structure is not yet determined with a satisfactory, reliable coefficient $\mathrm{R}$. The ambient temperature powder X-ray diffractogram shown in Figure 1 indicates that the title compound is well crystallized. 


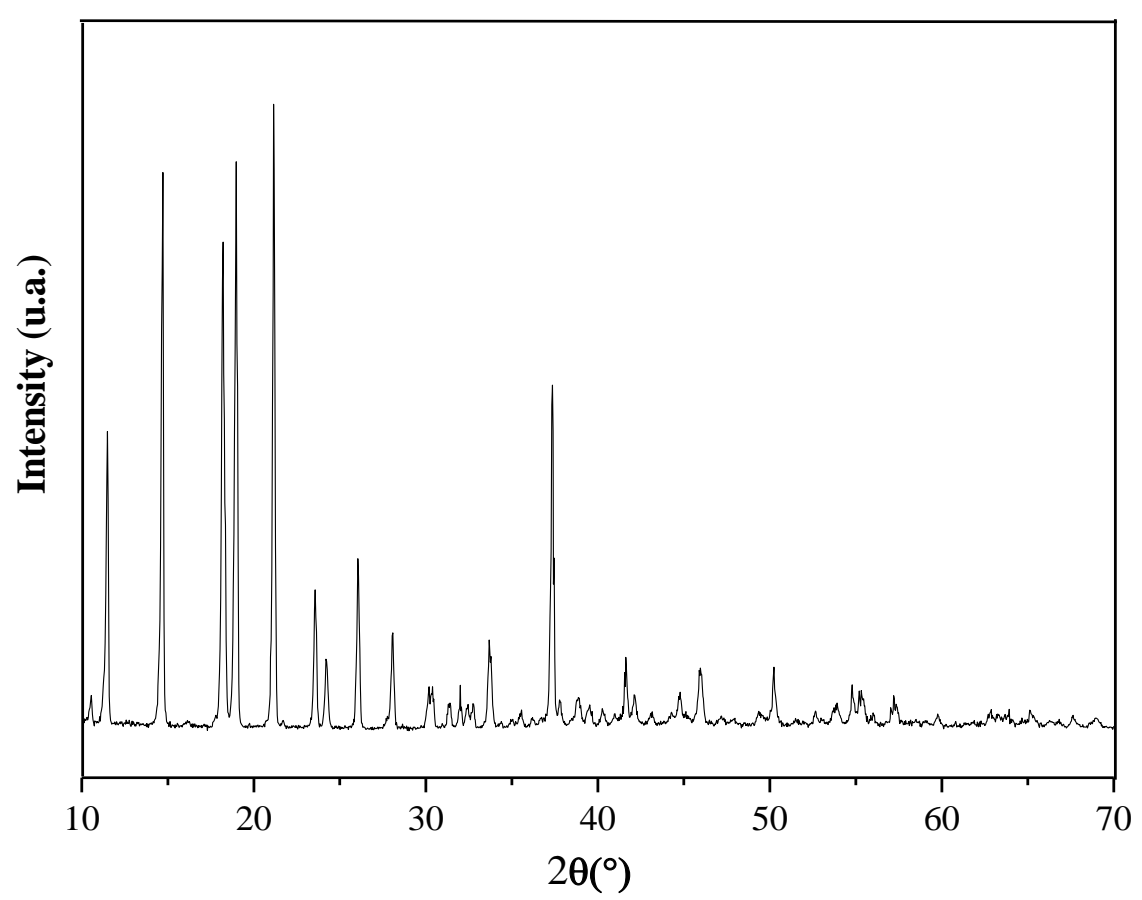

Figure 1. The powder X-Ray diffractogram of $\mathrm{NH}_{3}\left(\mathrm{CH}_{2}\right)_{3} \mathrm{NH}_{3} \mathrm{SiF}_{6}$ compound measured at ambient temperature.

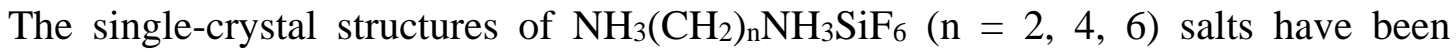
completely determined [25-27], which allowed us to make a comparative study between these compounds' structures. Based on the crystallographic data obtained for these compounds (Table 1), one can predict the structure of $\mathrm{NH}_{3}\left(\mathrm{CH}_{2}\right)_{3} \mathrm{NH}_{3} \mathrm{SiF}_{6}$, which is not fully determined until now. The $\mathrm{NH}_{3}\left(\mathrm{CH}_{2}\right)_{n} \mathrm{NH}_{3} \mathrm{SiF}_{6}(\mathrm{n}=2,3)$ compounds crystallized in the monoclinic system with the space groups $\left(P 2_{1} / \mathrm{n}, \mathrm{Z}=2\right)$ for $\mathrm{n}=2$ and $\left(P 2_{1} / \mathrm{c}, \mathrm{Z}=4\right)$ for $\mathrm{n}=3$, with different lattice parameters and unit cell volume values (Table 1). The changes concern particularly the $(\mathrm{Z}, \beta$, V) parameters when passing from $\left(2 ; 93.84(1)^{\circ} ; 148.13(7) \AA^{3}\right)$ in the compound with $(\mathrm{n}=2)$ to $\left(4 ; 117^{\circ} ; 1702 \AA^{3}\right)$ in the present studied compound $(\mathrm{n}=3)$.

Table 1: Crystallographic data of the alkylenediammonium hexafluorosilicate compounds

\begin{tabular}{|c|c|c|c|c|}
\hline Compounds & System & Space group & Unit cell parameters & References \\
\hline $\mathrm{NH}_{3}\left(\mathrm{CH}_{2}\right)_{2} \mathrm{NH}_{3} \mathrm{SiF}_{6}$ & Monoclinic & $\mathrm{P} 2{ }_{1} / \mathrm{n}(\mathrm{Z}=2)$ & $\begin{array}{c}\mathrm{a}=7.351(3) \AA \\
\mathrm{b}=8.732(3) \AA \\
\mathrm{c}=5.819(2) \AA \\
\beta=93.84(1)^{\circ} \\
\mathrm{V}=148.13(7) \AA^{3}\end{array}$ & [23] \\
\hline $\mathrm{NH}_{3}\left(\mathrm{CH}_{2}\right)_{3} \mathrm{NH}_{3} \mathrm{SiF}_{6}$ & Monoclinic & $\mathrm{P} 2{ }_{1} / \mathrm{c}(\mathrm{Z}=4)$ & $\begin{array}{c}\mathrm{a}=17.34 \AA \\
\mathrm{b}=5.88 \AA \\
\mathrm{c}=18.86 \AA \\
\beta=117^{\circ} \\
\mathrm{V}=1702 \AA^{3}\end{array}$ & Present work \\
\hline $\mathrm{NH}_{3}\left(\mathrm{CH}_{2}\right)_{4} \mathrm{NH}_{3} \mathrm{SiF}_{6}$ & Triclinic & $\mathrm{P}-1(\mathrm{Z}=1)$ & $\begin{array}{c}\mathrm{a}=5.796(1) \AA \\
\mathrm{b}=5.889(1) \AA \\
\mathrm{c}=7.774(2) \AA \\
\alpha=87.02(1)^{\circ} \\
\beta=82.15(1)^{\circ} \\
\gamma=61.87(1)^{\circ} \\
\mathrm{V}=231.79(8) \AA^{3}\end{array}$ & {$[24]$} \\
\hline $\mathrm{NH}_{3}\left(\mathrm{CH}_{2}\right)_{6} \mathrm{NH}_{3} \mathrm{SiF}_{6}$ & Triclinic & $\mathrm{P}-1(\mathrm{Z}=2)$ & $\begin{array}{c}\mathrm{a}=5.8965(2) \AA \\
\mathrm{b}=13.6946(5) \AA \\
\mathrm{c}=14.4945(5) \AA \\
\alpha=91.379(2)^{\circ} \\
\beta=92.797(2)^{\circ} \\
\gamma=90.906(2)^{\circ} \\
\mathrm{V}=1168.53(7) \AA^{3}\end{array}$ & [25] \\
\hline
\end{tabular}


The structure of $\mathrm{NH}_{3}\left(\mathrm{CH}_{2}\right)_{3} \mathrm{NH}_{3} \mathrm{SiF}_{6}$ compound may be built up from four $\mathrm{SiF}_{6}{ }^{2-}$ anions located on the moiety of the inversion centers $4 \mathrm{C}_{\mathrm{i}}(2)$ corresponding to the Wyckoff positions of the space group [2a, 2b, 2c, 2d] and four propylenediammonium cations placed on the general positions $\mathrm{C}_{1}(4)$ compatible with the Wyckoff positions $4 \mathrm{e}$. The non-centrosymmetric ${ }^{+} \mathrm{NH}_{3}\left(\mathrm{CH}_{2}\right)_{3} \mathrm{NH}_{3}{ }^{+}$cations are assumed to be of $\mathrm{C}_{1}$ symmetry. The anions may be linked to the organic cations through hydrogen bonds, which are characteristic of organic-inorganic hexafluorosilicate compounds [25-27].

The V/Z ratio variation ( $\mathrm{V}$ : cell volume, $\mathrm{Z}$ : number of motifs per cell) versus the $\mathrm{CH}_{2}$ groups' number ( $\mathrm{n}=2,3,4,6)$ in the $\mathrm{NH}_{3}\left(\mathrm{CH}_{2}\right)_{n} \mathrm{NH}_{3} \mathrm{SiF}_{6}$ compounds is given in Figure 2 . The variation is not linear. A deviation is observed when going from $n=3$ to 4 , i.e., when passing from the monoclinic system observed for the compounds $(\mathrm{n}=2,3)$ to the compounds' triclinic system $(n=4,6)$. The change from the monoclinic symmetry to the triclinic one occurs with an appreciable deviation in the unit cell volume values.

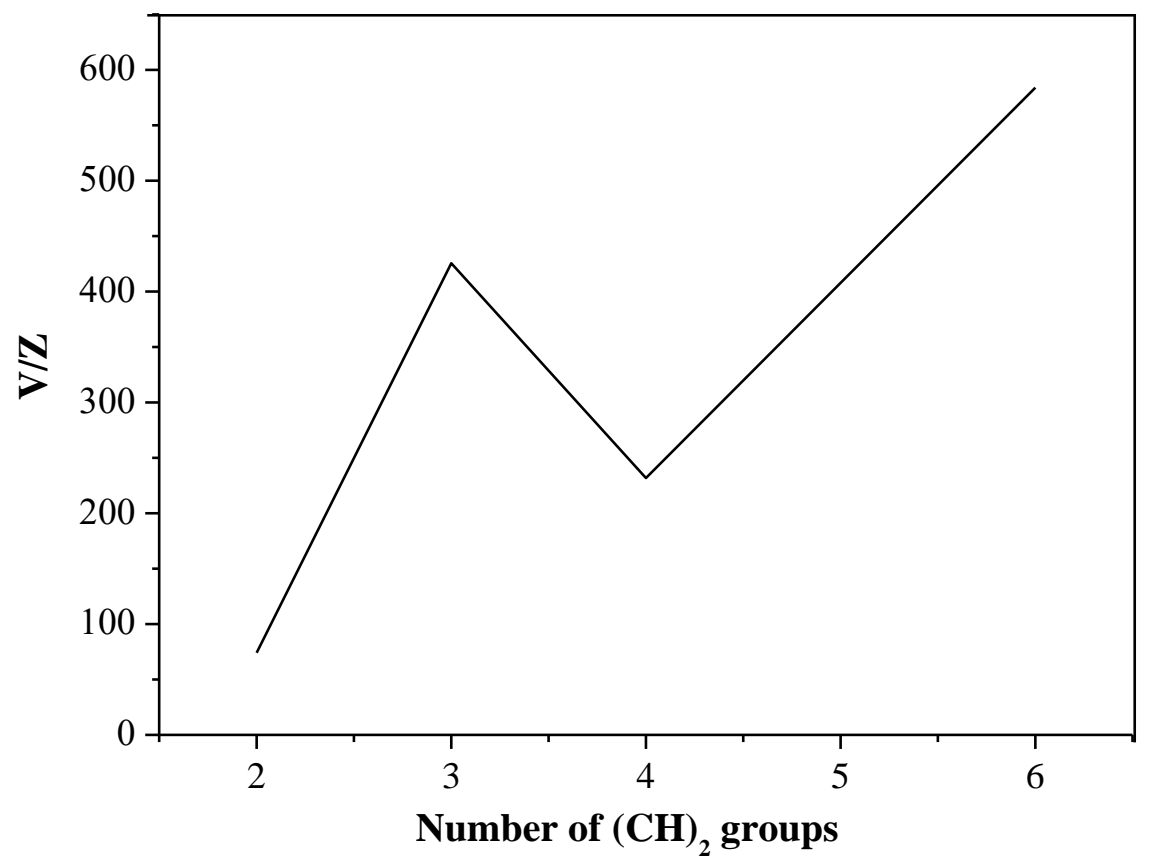

Figure 2. The variation of the cell volume $(\mathrm{V}) /$ number of motif per cell $(\mathrm{Z})$ with number " $\mathrm{n}$ " of $\left(\mathrm{CH}_{2}\right)$ groups in the hexafluorosilicate $\mathrm{NH}_{3}\left(\mathrm{CH}_{2}\right)_{\mathrm{n}} \mathrm{NH}_{3} \mathrm{SiF}_{6}(\mathrm{n}=2,3,4,6)$.

\subsection{Thermal behavior analyses.}

\subsubsection{Differential scanning calorimetry (DSC).}

The DSC curves of $\mathrm{NH}_{3}\left(\mathrm{CH}_{2}\right)_{3} \mathrm{NH}_{3} \mathrm{SiF}_{6}$ recorded between 35 and $245^{\circ} \mathrm{C}$ are shown in Figure 3. In heating, a strong and broad peak was centered around $125^{\circ} \mathrm{C}$, which is not observed in the cooling. The irreversible heating anomaly indicates the title compound's decomposition process, which takes place above $30^{\circ} \mathrm{C}$. To cheeks that the compound is not stable, we have carried out the TG-dTG analyses in the studied DSC temperature domain.

\subsubsection{Thermogravimetric (TG-dTG).}

The thermogravimetric (TGA- dTG) curves of $\mathrm{NH}_{3}\left(\mathrm{CH}_{2}\right)_{3} \mathrm{NH}_{3} \mathrm{SiF}_{6}$ were recorded on heating runs $\left(5^{\circ} \mathrm{C} \cdot \mathrm{min}^{-1}\right)$ between $30^{\circ} \mathrm{C}$ and $245^{\circ} \mathrm{C}$ (Figure 4). The initial weight of the crystal used in the TG-dTG analyses is $\mathrm{m}_{\mathrm{i}}=10.291 \mathrm{mg}$. The thermal decomposition process of the title compound begins at $30^{\circ} \mathrm{C}$. As shown in Figure 4, the compound's weight loss is $57.8 \%$ 
over the decomposition process $\left(30-245^{\circ} \mathrm{C}\right)$. The compound decomposition is illustrated by the endothermic DSC anomaly, which appeared at around $125^{\circ} \mathrm{C}$.

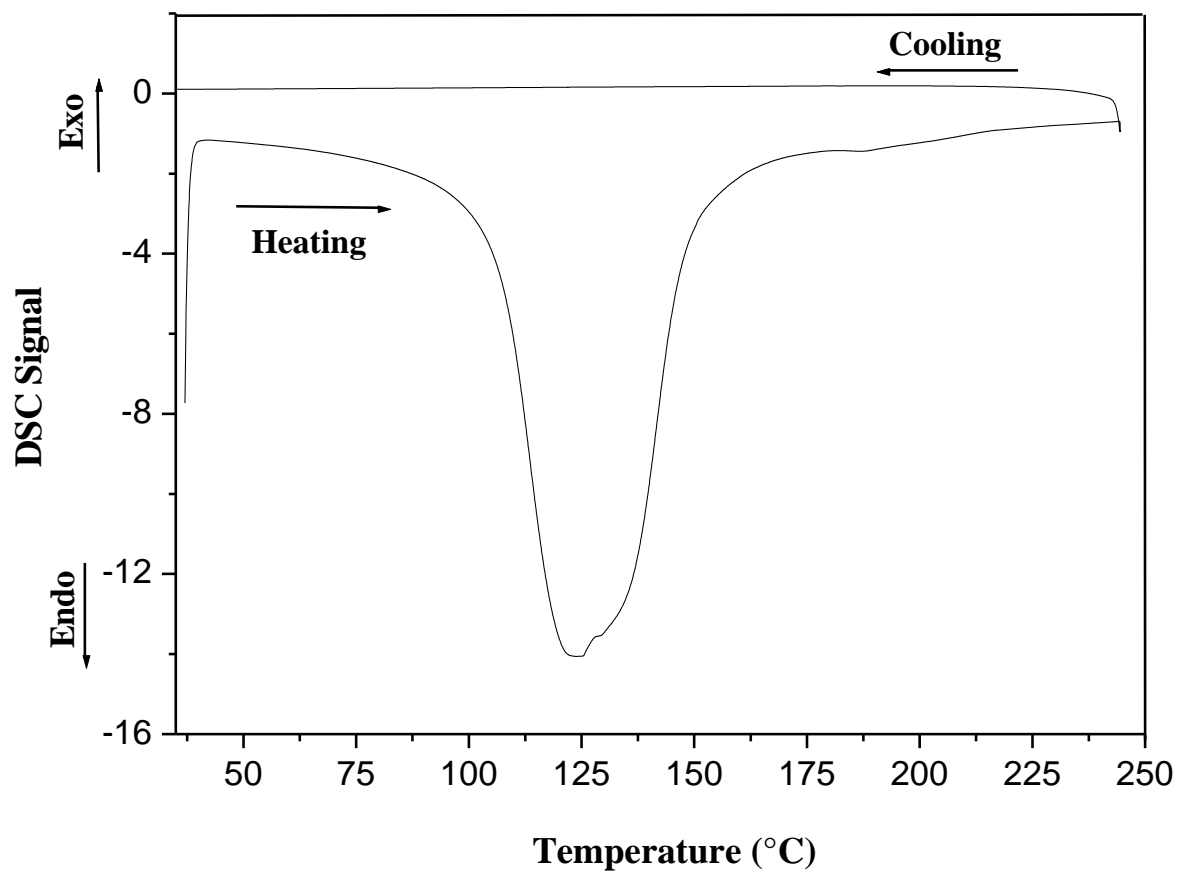

Figure 3. DSC curves of $\mathrm{NH}_{3}\left(\mathrm{CH}_{2}\right)_{n} \mathrm{NH}_{3} \mathrm{SiF}_{6}$ compound on heating and cooling runs $\left(10^{\circ} \mathrm{C} \mathrm{min}^{-1}\right)$ in the 35 $245^{\circ} \mathrm{C}$ temperature range.

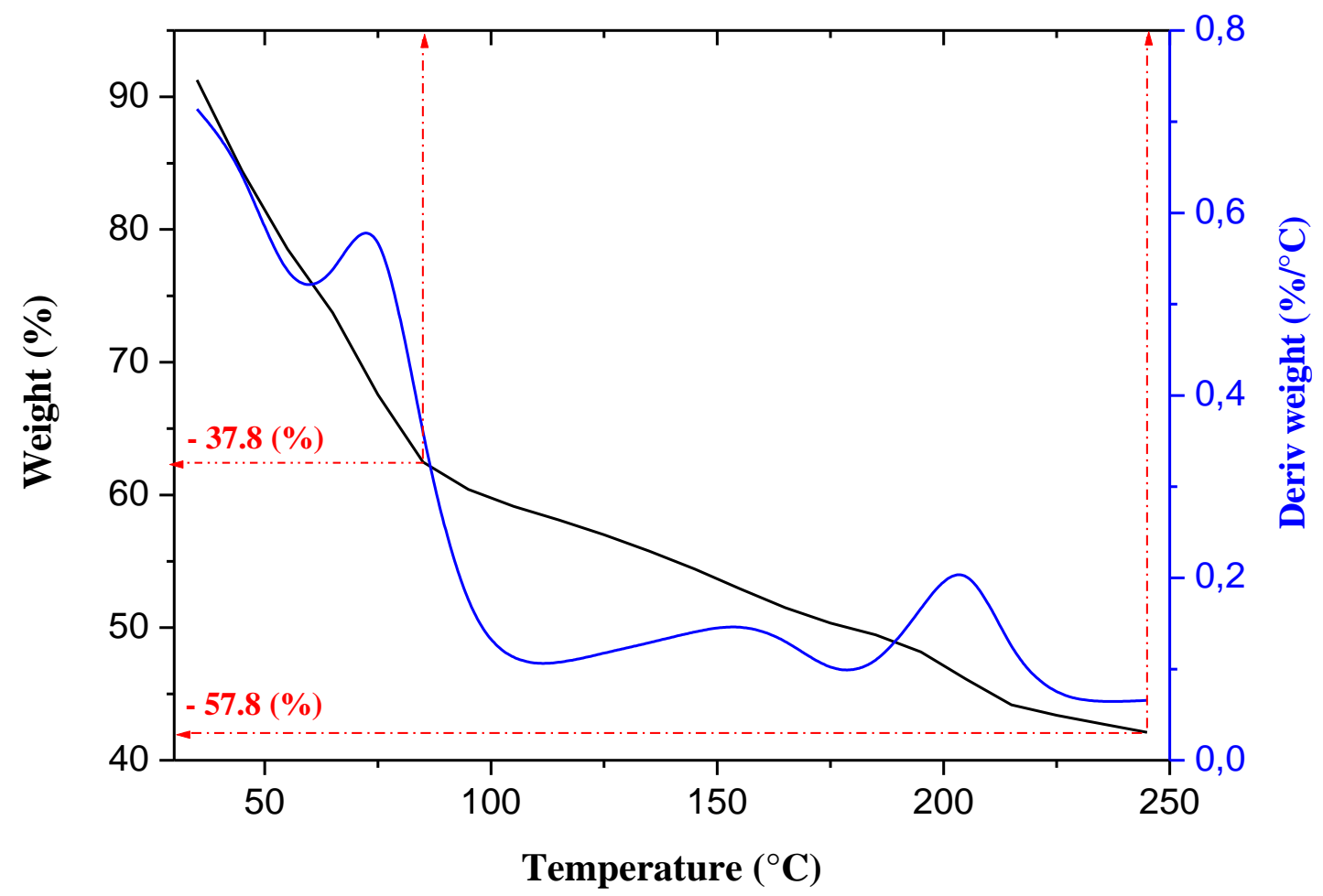

Figure 4. TG-dTG curves $\left(5^{\circ} \mathrm{C} \cdot \mathrm{min}^{-1}\right)$ measured for $\mathrm{NH}_{3}\left(\mathrm{CH}_{2}\right)_{\mathrm{n}} \mathrm{NH}_{3} \mathrm{SiF}_{6}$ in the $35-245^{\circ} \mathrm{C}$ temperature range.

The estimated weight loss at $85^{\circ} \mathrm{C}\left[\left(\Delta \mathrm{m} / \mathrm{m}_{\mathrm{i}}=37.8 \%\right.\right.$, i.e. $\left.\Delta \mathrm{m}=3.89 \mathrm{mg}\right)$ is due to the first decomposition step of the crystal. The second decomposition step is made between $85{ }^{\circ} \mathrm{C}$ and $245^{\circ} \mathrm{C}$, giving rise to the estimated total weight loss : $\Delta \mathrm{m} / \mathrm{m}_{\mathrm{i}}=57.8 \%$ (i.e. $\Delta \mathrm{m}=5.95 \mathrm{mg}$ ). Based on literature data [41-43], the $\mathrm{NH}_{3}\left(\mathrm{CH}_{2}\right)_{3} \mathrm{NH}_{3} \mathrm{SiF}_{6}$ thermal decomposition may be described by the proposed equation: 


$$
\mathrm{NH}_{3}\left(\mathrm{CH}_{2}\right)_{3} \mathrm{NH}_{3} \mathrm{SiF}_{6}(\mathrm{~s}) \rightarrow \mathrm{SiF}_{4}(\mathrm{~s})+2 \mathrm{HF}_{(\mathrm{g})}+\mathrm{N}_{2}(\mathrm{~g})+3 \mathrm{C}_{(\mathrm{g})}+5 \mathrm{H}_{2}(\mathrm{~g})
$$

The equation suggests that each mole of $\mathrm{NH}_{3}\left(\mathrm{CH}_{2}\right)_{3} \mathrm{NH}_{3} \mathrm{SiF}_{6}\left(218.1 \mathrm{~g}^{-\mathrm{mol}^{-1}}\right)$ gives 3 moles of carbon $\left(36\right.$ g.mol $\left.{ }^{-1}\right), 5$ moles of $\mathrm{H}_{2}\left(4 \mathrm{~g}^{\mathrm{mol}}{ }^{-1}\right), 1$ mole of $\mathrm{N}_{2}, 2$ moles of $\mathrm{HF}$ ( 20 g.mol $\left.{ }^{-1}\right)$, and 1 mole of $\mathrm{SiF}_{4}\left(104.1 \mathrm{~g}^{\mathrm{mol}}{ }^{-1}\right)$. The calculated $\mathrm{m}(\mathrm{C}), \mathrm{m}\left(\mathrm{H}_{2}\right), \mathrm{m}\left(\mathrm{N}_{2}\right)$, and $\mathrm{m}(\mathrm{HF})$ in the initial crystal weight are given as the following:

$$
\begin{aligned}
& {\left[\mathrm{m}(\mathrm{C})=\left(\mathrm{m}_{\mathrm{i}} / 218.1\right) \times 3 \mathrm{M}(\mathrm{C})=(10.291 / 218.1) \times 36=1.6987 \mathrm{mg}\right]} \\
& {\left[\mathrm{m}\left(\mathrm{H}_{2}\right)=\left(\mathrm{m}_{\mathrm{i}} / 218.1\right) \times 10 \mathrm{M}(\mathrm{H})=(10.291 / 218.1) \times 10=0.4718 \mathrm{mg}\right]} \\
& {\left[\mathrm{m}\left(\mathrm{N}_{2}\right)=\left(\mathrm{m}_{\mathrm{i}} / 218.1\right) \times 2 \mathrm{M}(\mathrm{N})=(10.291 / 218.1) \times 28=1.3212 \mathrm{mg}\right]} \\
& {\left[\mathrm{m}(\mathrm{HF})=\left(\mathrm{m}_{\mathrm{i}} / 218.1\right) \times 2 \mathrm{M}(\mathrm{HF})=(10.291 / 218.1) \times 40=1.8874 \mathrm{mg}\right]}
\end{aligned}
$$

As indicated in Figure 4, the first decomposition step is done at $37.8 \%$ with an estimate weight loss of $\Delta \mathrm{m}=3.89 \mathrm{mg}$, which is nearly close to the calculated mass for the $\mathrm{C}, \mathrm{H}_{2}$, and $\mathrm{N}_{2}$ in the initial crystal weight $\left[\left(\mathrm{m}(\mathrm{C})+\mathrm{m}\left(\mathrm{H}_{2}\right)+\mathrm{m}\left(\mathrm{N}_{2}\right)=3.4917 \mathrm{mg}\right]\right.$. Over the second decomposition step, the estimated total wheight loss at $245^{\circ} \mathrm{C}$ is $\Delta \mathrm{m}=5.95 \mathrm{mg}$ (Figure 4). This value is close to the loss weight calculated as $\left[\mathrm{m}(\mathrm{C})+\mathrm{m}\left(\mathrm{H}_{2}\right)+\mathrm{m}\left(\mathrm{N}_{2}\right)+\mathrm{m}(\mathrm{HF})=5.3791 \mathrm{mg}\right]$. At this temperature, the remaining $\mathrm{m}\left(\mathrm{SiF}_{4}\right)$ in the initial crystal weight is calculated as: $[(10.291 / 218.1) \times 104.1=4.9119 \mathrm{mg}]$.

The TGA-dTG analyses indicate the title compound's decomposition processes over the $30-245^{\circ} \mathrm{C}$ temperature domain, as highlighted by the DSC technique in the corresponding temperature domain.

\subsection{Group theoretical analyses.}

The theoretical group analysis of the number and the symmetry of the normal modes is developed according to the crystal structure data obtained from the XRD study of $\mathrm{NH}_{3}\left(\mathrm{CH}_{2}\right)_{2} \mathrm{NH}_{3} \mathrm{SiF}_{6}$ compound, which is a monoclinic system, $P 2{ }_{1} / \mathrm{c}(\mathrm{Z}=4)$ space group.

\subsubsection{Vibrational modes of $+\mathrm{NH}_{3}\left(\mathrm{CH}_{2}\right)_{3} \mathrm{NH}_{3}{ }^{+}$cation.}

The free ${ }^{+} \mathrm{NH}_{3}\left(\mathrm{CH}_{2}\right)_{3} \mathrm{NH}_{3}{ }^{+}$cation considered in the $\mathrm{C}_{2}$ vsymmetry displays 45 internal vibrational modes described as $14 \mathrm{~A}_{1}(\mathrm{Ra}, \mathrm{IR})+9 \mathrm{~A}_{2}(\mathrm{Ra})+10 \mathrm{~B}_{1}(\mathrm{Ra}, \mathrm{IR})+10 \mathrm{~B}_{2}(\mathrm{Ra}, \mathrm{IR})$. Within the crystal of space group $P 2{ }_{1} / \mathrm{c}(\mathrm{Z}=4)\left(\mathrm{C}_{2 \mathrm{~h}}^{5}\right)$, the ${ }^{+} \mathrm{NH}_{3}\left(\mathrm{CH}_{2}\right)_{3} \mathrm{NH}_{3}{ }^{+}$cations are assumed to occupy the general positions of Wyckoff positions $(4 \mathrm{e})$ and are considered $\mathrm{C}_{1}$ symmetry sites.

Table 2. Correlation diagram of ${ }^{+} \mathrm{NH}_{3}\left(\mathrm{CH}_{2}\right)_{3} \mathrm{NH}_{3}{ }^{+}$internal vibrational modes in the crystal.

\begin{tabular}{l|l|l} 
Molecular group $\left(\mathbf{C}_{2 \mathbf{v}}\right)$ & Site group $\left(\mathbf{C}_{\mathbf{1}}\right)$ & Factor group $\left(\mathbf{C}_{2 \mathbf{h}}\right)$ \\
\hline $14 \mathrm{~A}_{1}(\mathrm{Ra}, \mathrm{IR})$ & \\
\hline
\end{tabular}

In the $\mathrm{C}_{1}$ site group (Table 2), the cationic vibrational modes are of the A symmetry, all infrared, and Raman actives. By the crystal field effect (Davydov splitting effect) due to the existence of 4 cations per primitive unit cell, each of $45 \mathrm{~A}$ internal modes of cations in the site group should theoretically split into four components $\left(\mathrm{Ag}_{\mathrm{g}}, \mathrm{B}_{\mathrm{g}}\right)$ actives in Raman and $\left(\mathrm{A}_{\mathrm{u}}, \mathrm{B}_{\mathrm{u}}\right)$ 
actives in Infrared. So, the 180 cationic internal modes predicted in the crystal are described as $\left[45 \mathrm{Ag}(\mathrm{Ra})+45 \mathrm{Au}_{\mathrm{u}}(\mathrm{IR})+45 \mathrm{Bg}(\mathrm{Ra})+45 \mathrm{~B}_{\mathrm{u}}(\mathrm{IR})\right]$; the gerade modes are Raman actives, whereas the ungerade are infrared actives in respect of the selection rules implied by the centrosymmetric of the crystal.

\subsubsection{Vibrational modes of $\mathrm{SiF}_{6}^{2-}$ anion.}

The free $\mathrm{SiF}_{6}{ }^{2-}$ anion of $\mathrm{O}_{\mathrm{h}}$ symmetry undergoes 15 internal normal modes, which are classified as: $1 A_{1 g}(R)+1 E_{g}(R)+1 F_{2 g}(R)+2 F_{1 u}(I R)+1 F_{2 u}(I n)$. The vibrational modes $\left(A_{1 g}\right.$, $\left.E_{g}, F_{2 g}\right)$ are Raman-active; those of $F_{1 u}$ type are infrared active and should appear as single bands, whereas the $\mathrm{F}_{2 \mathrm{u}}$ modes are inactive.

In the crystal of the $P 2{ }_{1} / \mathrm{c}(\mathrm{Z}=4)$ space group, the $\mathrm{SiF}_{6}{ }^{2-}$ anions are assumed to occupy the sites' symmetry $C_{i}(2)$. By the site effect (Table 3), the A1g, $E_{g}, F_{2 g}$ modes become of $A_{g}$ symmetry, with splitting of $E_{g}$ and F2g modes into two and three Raman active components, respectively. Besides, the infrared active $F_{1 u}$ and the inactive $F_{2 u}$ modes become split each other into three components of $\mathrm{A}_{u}$ symmetry, all active in Infrared. Under the crystal field effect (Davydov splitting effect), the gerade modes $\mathrm{Ag}_{\mathrm{g}}$ should split into two ( $\mathrm{Ag}, \mathrm{Bg}$ ) active in Raman, and the ungerade $\mathrm{F} 1 \mathrm{u}$ to two components $\left(\mathrm{A}_{\mathrm{u}}, \mathrm{B}_{\mathrm{u}}\right)$ active in Infrared. This gives in the group factor 180 internal modes described as $\left[45 \mathrm{Ag}_{\mathrm{g}}(\mathrm{Ra})+45 \mathrm{~A}_{\mathrm{u}}(\mathrm{IR})+45 \mathrm{~B}_{\mathrm{g}}(\mathrm{Ra})+45 \mathrm{~B}_{\mathrm{u}}(\mathrm{IR})\right]$. Splitting of the vibrational modes in the solid-state is expected for $\mathrm{SiF}_{6}{ }^{2-}$ in the crystal by lowering of the symmetry $\left(\mathrm{O}_{\mathrm{h}} \rightarrow \mathrm{C}_{\mathrm{i}}\right)$.

Table 3. Correlation diagram of $\mathrm{SiF}_{6}^{2-}$ internal vibrational modes in the crystal.

\begin{tabular}{l|l|l} 
Molecular symmetry $(\mathbf{O h})$ & Site symmetry $\left(\mathbf{C}_{\mathbf{i}}\right)$ & Factor Group $\left(\mathbf{C}_{2 \mathbf{h}}\right)$ \\
\hline$v_{1}: 1 \mathrm{~A} 1 \mathrm{~g}(\mathrm{Ra})$ & \\
\hline$v_{2}: 1 \mathrm{Eg}(\mathrm{Ra})$ & $\mathrm{Ag}(\mathrm{Ra})$ \\
\hline$v_{5}: 1 \mathrm{~F} 2 \mathrm{~g}(\mathrm{Ra})$
\end{tabular}

\subsection{Infrared and Raman spectra interpretation.}

The Raman spectrum of $\mathrm{NH}_{3}\left(\mathrm{CH}_{2}\right)_{3} \mathrm{NH}_{3} \mathrm{SiF}_{6}$ is presented in Figure 5. The Infrared spectrum is divided into two regions $\left(4000-1800 \mathrm{~cm}^{-1}, 1800-400 \mathrm{~cm}^{-1}\right)$ as illustrated in Figures 6 (a-b). The vibrational spectra study is assisted by the normal vibrational modes predicted by the theoretical group analysis (Tables 2 and 3) and previous work on alkylammonium and alkylenediammonium salts [23, 28, 44-46]. The IR spectrum of the title compound is similar to those of $\mathrm{NH}_{3}\left(\mathrm{CH}_{2}\right)_{n} \mathrm{NH}_{3} \mathrm{SiF}_{6}(\mathrm{n}=4,6)$ [28], which confirms the existence of the $\mathrm{SiF}_{6}{ }^{2-}$ and the cations ${ }^{+} \mathrm{NH}_{3}\left(\mathrm{CH}_{2}\right)_{3} \mathrm{NH}_{3}{ }^{+}$in the present compound.

The Raman spectrum (Figure 5) highlights little clear bands observed at 2995, 960, 654 $\mathrm{cm}^{-1}$, which can be assigned to the $v_{\mathrm{as}}\left(\mathrm{CH}_{2}\right), v_{\text {as }}(\mathrm{CN})$, and $v_{1}\left(v_{\mathrm{s}} \mathrm{Si}-\mathrm{F}\right)$ vibrational modes. These peaks refer to the organic and inorganic components. It is observed the fluorescent shape which ascribes to the organic and inorganic parts in the Raman spectrum, which infers that the structural characterization of the bulk crystal is not efficient. It is to note that the more resolved 
spectrum for the studied crystal is observed at the fixed power $\mathrm{P}=6.0 \mathrm{~mW}$, with the wavelength Laser at $455 \mathrm{~nm}$.

The infrared spectrum of $\mathrm{NH}_{3}\left(\mathrm{CH}_{2}\right)_{3} \mathrm{NH}_{3} \mathrm{SiF}_{6}$ in the $3300-2800 \mathrm{~cm}^{-1}$ region contains appreciable bands due to N-H and C-H stretching modes of $\mathrm{NH}_{3}$ and $\left(\mathrm{CH}_{2}\right)_{3}$ groups (Figure 6.a). The weak IR band observed at $3207 \mathrm{~cm}^{-1}$, and the strong band at $3063 \mathrm{~cm}^{-1}$ are assigned to asymmetric $v_{\text {as }}\left(\mathrm{NH}_{3}\right)$ and symmetric $v_{\mathrm{s}}\left(\mathrm{NH}_{3}\right)$ stretching modes, respectively. The two strong IR bands observed at 3009 and $2960 \mathrm{~cm}^{-1}$ with a shoulder at $2980 \mathrm{~cm}^{-1}$ correspond to the $\mathrm{CH}_{2}$ asymmetric stretching modes $v_{\text {as }}\left(\mathrm{CH}_{2}\right)$, which give rise to a strong band in the Raman spectrum at $2995 \mathrm{~cm}^{-1}$. The medium IR band located at $2893 \mathrm{~cm}^{-1}$ corresponds to the $\mathrm{CH}_{2}$ symmetric stretching modes $v_{\mathrm{s}}\left(\mathrm{CH}_{2}\right)$.

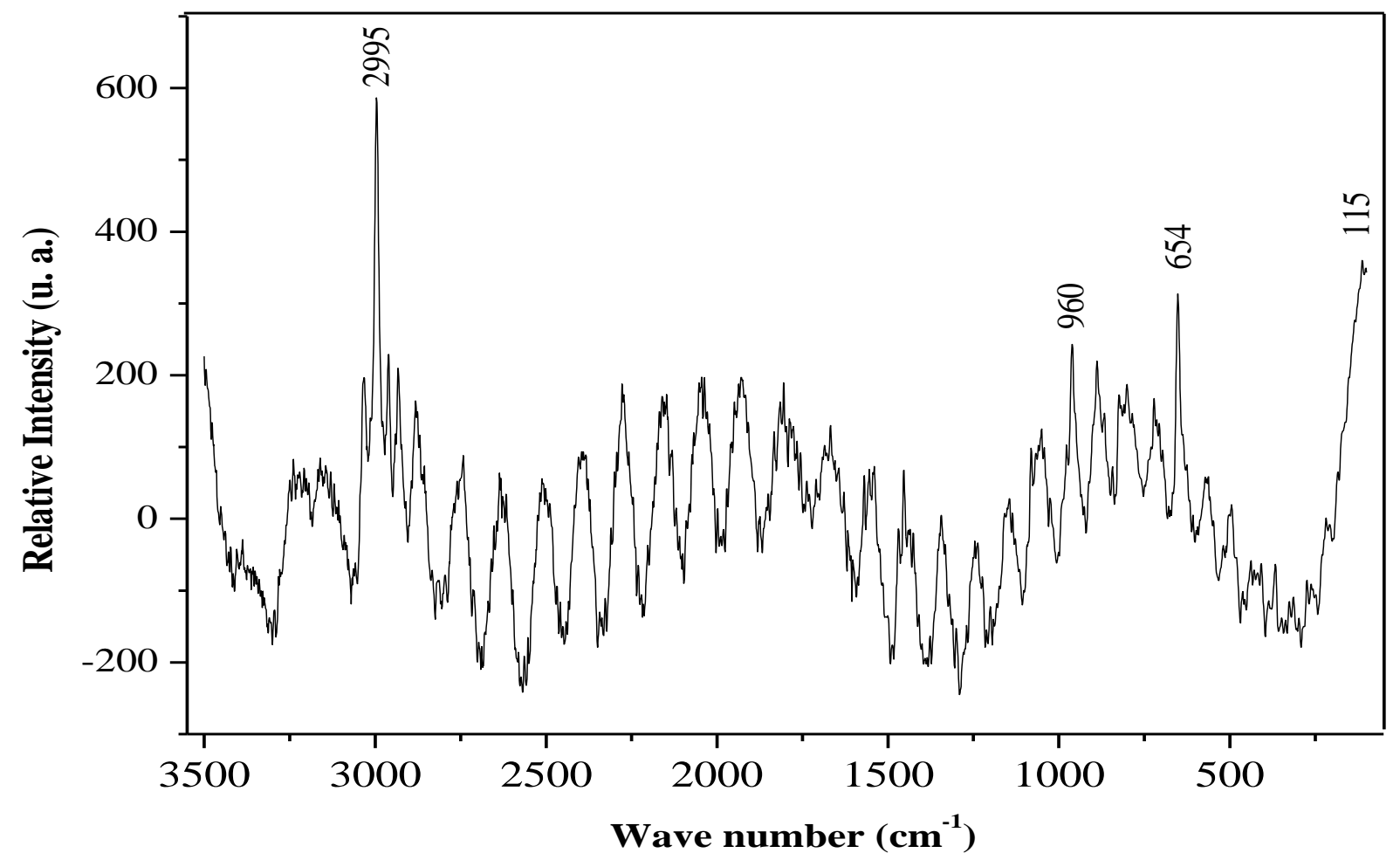

Figure 5. The Ramanspectrum of $\mathrm{NH}_{3}\left(\mathrm{CH}_{2}\right)_{3} \mathrm{NH}_{3} \mathrm{SiF}_{6}$ was recorded at ambient temperature in the $4000-25 \mathrm{~cm}^{-1}$ spectral range.

At lower wavenumbers of $\mathrm{NH}$ and $\mathrm{CH}$ stretching spectral region (Figure 6a), the nonfundamental bands of weak to medium intensities observed between 2768 and $1965 \mathrm{~cm}^{-1}$ are originated by the Fermi resonance between the fundamental $\mathrm{CH}_{2}$ stretching and the overtone or combination bands of $\mathrm{CH}_{2}$ bending modes, as has been found in several hybrid compounds $[2,4,28]$. The appearance of these modes with appreciable intensities at lower $\mathrm{NH}$ and $\mathrm{CH}$ stretching frequencies is an indication that hydrogen bonding $\mathrm{N}-\mathrm{H} . . . \mathrm{F}$ takes place between anions and cation in the $\mathrm{NH}_{3}\left(\mathrm{CH}_{2}\right)_{3} \mathrm{NH}_{3} \mathrm{SiF}_{6}$ compound. The assignment of the IR nonfundamental bands to combination and overtone modes is proposed in Table 5.

The medium bands observed at 1630 and $1600 \mathrm{~cm}^{-1}$ (Figure 6b) were attributed to the asymmetric bending modes $\delta_{\text {as }}\left(\mathrm{NH}_{3}\right)$ (scissoring). The spectral range $1500-1190 \mathrm{~cm}^{-1}$ of the title compound consists of bands owing to the bending $\mathrm{CH}_{2}$ modes of the $\left(\mathrm{CH}_{2}\right)_{3}$ chains. As previously suggested, these bands are spread over a large spectral region [23, 28, 44]. Indeed, the strong IR bands observed at $1478 \mathrm{~cm}^{-1}$ and $1463 \mathrm{~cm}^{-1}$ were assigned to the $\delta\left(\mathrm{CH}_{2}\right)$ scissoring modes (Table 4). The wagging and twisting $\mathrm{CH}_{2}$ vibrational modes are observed in the 1410- 
$1215 \mathrm{~cm}^{-1}$ frequency region; the $\delta\left(\mathrm{CH}_{2}\right)$ wagging modes exhibit a medium IR band at $1409 \mathrm{~cm}^{-}$ ${ }^{1}$, whereas the $\delta\left(\mathrm{CH}_{2}\right)$ twisting modes give rise to a band of medium intensity at $1217 \mathrm{~cm}^{-1}$.
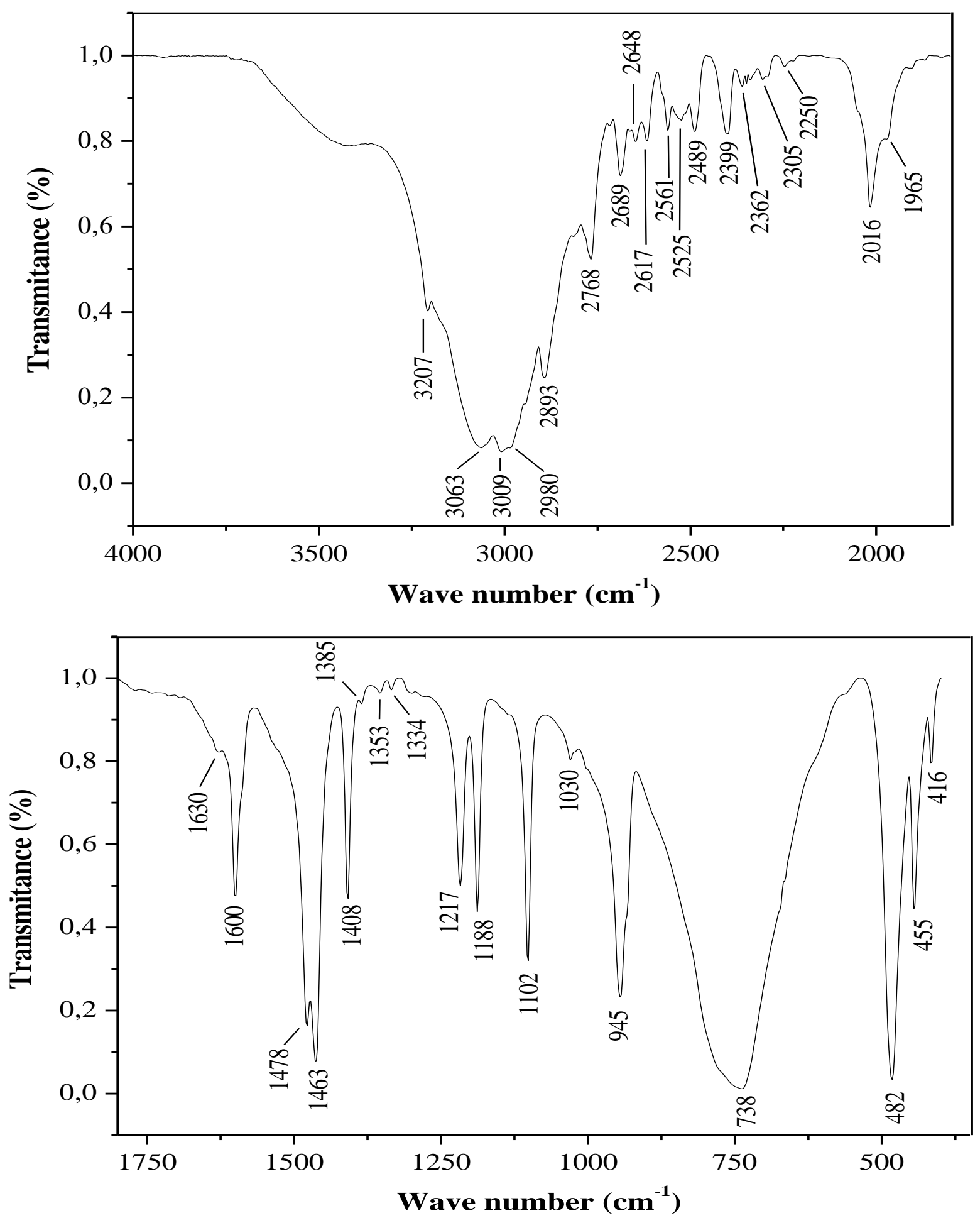

Figure 6. (a) TheInfrared spectrum of $\mathrm{NH}_{3}\left(\mathrm{CH}_{2}\right)_{3} \mathrm{NH}_{3} \mathrm{SiF}_{6}$ recorded at room temperature in the $4000-1800 \mathrm{~cm}^{-1}$ spectral range; (b) TheInfrared spectrum of $\mathrm{NH}_{3}\left(\mathrm{CH}_{2}\right)_{3} \mathrm{NH}_{3} \mathrm{SiF}_{6}$ recorded at ambient temperature in the 1800$400 \mathrm{~cm}^{-1}$ spectral range.

Other bands of weak intensities due to $\delta\left(\mathrm{CH}_{2}\right)$ wagging and twisting are observed in this region (Table 4). The rocking $\mathrm{CH}_{2}$ vibrations were found at lower frequencies as medium to strong bands in the $1220-730 \mathrm{~cm}^{-1}$ frequency range, as illustrated in Table 4 . The vibrational modes involving C-C and C-N stretching modes were observed in the $1190-940 \mathrm{~cm}^{-1}$ spectral region. In the alkylene chain, they are generally mixed with the $\mathrm{CH}_{2}$ and $\mathrm{NH}_{3}$ wagging and 
rooking modes $[23,28,44]$. The weak IR band observed at $1030 \mathrm{~cm}^{-1}$ is assigned to the $v(\mathrm{C}$ C) stretching vibrations; the strong band located at $945 \mathrm{~cm}^{-1}$ may be due to the $v(\mathrm{C}-\mathrm{N})$ modes. The skeletal bending modes $\delta(\mathrm{CCN})$ and $\delta(\mathrm{CCC})$ may contribute to the strong and broadband observed at $445 \mathrm{~cm}^{-1}$, while the $\delta_{\mathrm{s}}(\mathrm{CNC})$ are observed at $416 \mathrm{~cm}^{-1}$ as weak band.

The vibrational modes of the $\mathrm{SiF}_{6}{ }^{2-}$ anions were generally observed below $700 \mathrm{~cm}^{-1}$ as shown in the Infrared spectrum (Figure 6.b) and Table 4. The theoretical analysis of the IR and Raman vibrational modes of the $\mathrm{SiF}_{6}{ }^{2-}$ anion in $\mathrm{O}_{\mathrm{h}}$ and $\mathrm{C}_{\mathrm{i}}$ symmetries is shown in Table 3, suggesting normal modes are splitting by lowering the anion symmetry. This may reliably support the vibrational assignments made particularly in the Infrared spectrum. The results obtained are compared to the literature data $[4,11,12]$.

In the Infrared spectrum, the four bands observed at $738,482,445$, and $416 \mathrm{~cm}^{-1}$ may be due to the SiF62- anions' vibrational modes. Indeed, the strong and broadband observed at $738 \mathrm{~cm}^{-1}$ may be originated from the $v_{3}\left(v_{\text {as }} S i-F\right)$ modes of $F_{1 u}$ symmetry, which theoretically should be Infrared active (Table 3). The broadening of this band may have resulted as well in the splitting of the $v_{3}\left(v_{\text {as }} \mathrm{Si}-\mathrm{F}\right)$ vibrational mode in the crystal $\left(\mathrm{C}_{\mathrm{i}}\right.$ factor group $)$ and in the overlapping of other modes coming from the cationic skeletal such as $\delta(\mathrm{CCN})$ and $\delta(\mathrm{CCC})$ vibrations. The $v_{4}\left(\delta_{\text {as }} \mathrm{F}-\mathrm{Si}-\mathrm{F}\right)$ modes of symmetry $\mathrm{F}_{1 \mathrm{u}}$ are observed at $482 \mathrm{~cm}^{-1}$ as a very strong band. At $445 \mathrm{~cm}^{-1}$ as a medium band, confirming the splitting of these degenerated modes as predicted theoretically in Table 4.

In agreement with the $\mathrm{Ci}$ factor group analysis, the Raman active modes of symmetry $\mathrm{Ag}\left[v_{1}\left(v_{\mathrm{s}} \mathrm{Si}-\mathrm{F}\right)\right], \mathrm{Eg}\left[v_{2}\left(v_{\mathrm{s}} \mathrm{Si}-\mathrm{F}\right)\right]$ and $\mathrm{F}_{2 \mathrm{~g}}\left[v_{5}\left(\delta_{\mathrm{s}} \mathrm{F}-\mathrm{Si}-\mathrm{F}\right)\right]$ are not activated in the infrared spectrum of the title compound, which well confirms the predicted $\mathrm{C}_{\mathrm{i}}$ symmetry assigned to the anions in the crystal. The $v_{1}(v \mathrm{Si}-\mathrm{F})$ modes are observed only in the Raman spectrum as a medium band at $654 \mathrm{~cm}^{-1}$; the other modes $v_{2}\left(v_{\mathrm{s}} \mathrm{Si}-\mathrm{F}\right)$ and $v_{5}\left(\delta_{\mathrm{s}} \mathrm{F}-\mathrm{Si}-\mathrm{F}\right)$ are not appreciably observed due to the fluorescence ascribing to the anionic and cationic parts of the $\mathrm{NH}_{3}\left(\mathrm{CH}_{2}\right)_{3} \mathrm{NH}_{3} \mathrm{SiF}_{6}$ Raman spectrum.

Table 4. Assignment of Infrared and some Raman bands of $\mathrm{NH}_{3}\left(\mathrm{CH}_{2}\right)_{3} \mathrm{NH}_{3} \mathrm{SiF}_{6}$.

\begin{tabular}{|c|c|c|}
\hline IR & Raman & Assignment \\
\hline $3207 \mathrm{w}$ & & $v_{\text {as }}\left(\mathrm{NH}_{3}\right)$ \\
\hline $3063 \mathrm{~s}$ & & $v_{\mathrm{s}}\left(\mathrm{NH}_{3}\right)$ \\
\hline $\begin{array}{c}3009 \mathrm{~s} \\
2980 \mathrm{sh} \\
2960 \mathrm{~s}\end{array}$ & $2995 \mathrm{~s}$ & $v_{\text {as }}\left(\mathrm{CH}_{2}\right)$ \\
\hline $2893 \mathrm{~m}$ & & $v_{\mathrm{s}}\left(\mathrm{CH}_{2}\right)$ \\
\hline $1630 \mathrm{~m}$ & & $\delta_{\mathrm{as}}\left(\mathrm{NH}_{3}\right)$ \\
\hline $1600 \mathrm{~m}$ & & $\delta_{\mathrm{as}}\left(\mathrm{NH}_{3}\right)$ \\
\hline $1478 \mathrm{~s}$ & & $\delta\left(\mathrm{CH}_{2}\right)_{\mathrm{sci}} / \delta_{\mathrm{s}}\left(\mathrm{NH}_{3}\right)$ \\
\hline 1463 vs & & $\delta\left(\mathrm{CH}_{2}\right)_{\mathrm{sci}}$ \\
\hline $1409 \mathrm{~m}$ & & $\delta\left(\mathrm{CH}_{2}\right)_{\mathrm{wag}}+v(\mathrm{CC})$ \\
\hline $1385 \mathrm{vw}$ & & $\delta\left(\mathrm{CH}_{2}\right)_{\mathrm{wag}}+v(\mathrm{CC})$ \\
\hline $1353 \mathrm{w}$ & & $\delta\left(\mathrm{CH}_{2}\right)_{\mathrm{tw}}$ \\
\hline $1334 \mathrm{w}$ & & $\delta\left(\mathrm{CH}_{2}\right)_{\mathrm{tw}}$ \\
\hline $1217 \mathrm{~m}$ & & $\delta\left(\mathrm{CH}_{2}\right)_{\mathrm{tw}} / \delta\left(\mathrm{CH}_{2}\right)_{\mathrm{rok}}$ \\
\hline $1188 \mathrm{~m}$ & & $\delta\left(\mathrm{CH}_{2}\right)_{\text {rok }}+v(\mathrm{CC})$ \\
\hline $1102 \mathrm{~s}$ & & $\delta\left(\mathrm{NH}_{3}\right)_{\mathrm{rok}}$ \\
\hline \multirow[t]{2}{*}{$1030 \mathrm{w}$} & & $v(\mathrm{CC})$ \\
\hline & $960 \mathrm{~m}$ & Vas $(\mathrm{CN})$ \\
\hline $945 \mathrm{~s}$ & & $\delta\left(\mathrm{NH}_{3}\right)_{\mathrm{rok}}+v(\mathrm{CN})$ \\
\hline \multirow[t]{2}{*}{$738 \mathrm{~s}, \mathrm{~b}$} & & $v_{3}\left(v_{\text {as }} \mathrm{Si}-\mathrm{F}\right) / \delta\left(\mathrm{CH}_{2}\right)_{\text {rok }}$ \\
\hline & $654 \mathrm{~m}$ & $v_{1}\left(v_{s} \mathrm{Si}-\mathrm{F}\right)$ \\
\hline 482 vs & & $v_{4}\left(\delta_{\text {as }} \mathrm{F}-\mathrm{Si}-\mathrm{F}\right)$ \\
\hline $445 \mathrm{~m}$ & & $v_{4}\left(\delta_{\text {as }} \mathrm{F}-\mathrm{Si}-\mathrm{F}\right) / \delta(\mathrm{CCN}) / \delta(\mathrm{CCC})$ \\
\hline
\end{tabular}




\begin{tabular}{c|c|c} 
IR & Raman & Assignment \\
\hline $416 \mathrm{w}$ & & $\delta_{\mathrm{s}}(\mathrm{CNC})$ \\
\hline & $115 \mathrm{~m}$ & Lattice modes
\end{tabular}

vs :very strong, s: strong, m: medium, vw: very weak, w: weak, b: broad, sh: shoulder

Table 5. Assignment of the non-fundamental Infrared bands of $\mathrm{NH}_{3}\left(\mathrm{CH}_{2}\right)_{3} \mathrm{NH}_{3} \mathrm{SiF}_{6}$ (m: medium, w: weak, vw:

\begin{tabular}{l|c}
\multicolumn{1}{c}{ Band $\left(\mathbf{c m}^{-1}\right)$} & $\begin{array}{c}\text { very weak }) \\
\text { Assignment }\end{array}$ \\
\hline $2768 \mathrm{~m}$ & $\approx 2762=1409+1353:\left[\delta\left(\mathrm{CH}_{2}\right)_{\mathrm{wag}} / v(\mathrm{C}-\mathrm{C})+\delta\left(\mathrm{CH}_{2}\right)_{\mathrm{twi}}\right]$ \\
\hline $2689 \mathrm{~m}$ & $\approx 2680=1463+1217:\left[\delta\left(\mathrm{CH}_{2}\right)_{\mathrm{sci}}+\delta\left(\mathrm{CH}_{2}\right)_{\mathrm{twi}} / \delta\left(\mathrm{CH}_{2}\right)_{\mathrm{rok}}\right]$ \\
\hline $2648 \mathrm{w}$ & $\approx 2651=1463+1188:\left[\delta\left(\mathrm{CH}_{2}\right)_{\mathrm{sci}}+\left(\mathrm{CH}_{2}\right)_{\mathrm{rok}} / v(\mathrm{C}-\mathrm{C})\right]$ \\
\hline $2617 \mathrm{w}$ & $\approx 2626=1409+1217:\left[\delta\left(\mathrm{CH}_{2}\right)_{\mathrm{wag}} / v(\mathrm{C}-\mathrm{C})+\delta\left(\mathrm{CH}_{2}\right)_{\mathrm{twi}} / \delta\left(\mathrm{CH}_{2}\right)_{\mathrm{rok}}\right]$ \\
\hline $2561 \mathrm{w}$ & $\approx 2565=1463+1102:\left[\delta\left(\mathrm{CH}_{2}\right)_{\mathrm{sci}}+\delta\left(\mathrm{NH}_{3}\right)_{\mathrm{rok}}\right]$ \\
\hline $2525 \mathrm{w}$ & $\approx 2511=1409+1102:\left[\delta\left(\mathrm{CH}_{2}\right)_{\mathrm{wag}} / v(\mathrm{C}-\mathrm{C})+\delta\left(\mathrm{NH}_{3}\right)_{\mathrm{rok}}\right]$ \\
\hline $2489 \mathrm{w}$ & $\approx 2493=1463+1030:\left[\delta\left(\mathrm{CH}_{2}\right)_{\mathrm{sci}}+v(\mathrm{C}-\mathrm{C})\right]$ \\
\hline $2399 \mathrm{~m}$ & $\approx 2408=1463+945:\left[\delta\left(\mathrm{CH}_{2}\right)_{\mathrm{sci}}+\delta\left(\mathrm{NH}_{3}\right)_{\mathrm{rok}} / v(\mathrm{C}-\mathrm{N})\right]$ \\
\hline $2362 \mathrm{w}$ & $\approx 2364=1334+1030:\left[\delta\left(\mathrm{CH}_{2}\right)_{\mathrm{twi}}+v(\mathrm{C}-\mathrm{C})\right]$ \\
\hline $2305 \mathrm{w}$ & $\approx 2247=1217+1030:\left[\delta\left(\mathrm{CH}_{2}\right)_{\mathrm{twi}} / \delta(\mathrm{CH})_{\mathrm{rok}}+v(\mathrm{C}-\mathrm{C})\right]$ \\
\hline $2250 \mathrm{w}$ & $\approx 2016=1600+416:\left[\delta_{\mathrm{as}}\left(\mathrm{NH}_{3}\right)+\delta\left(\delta_{\mathrm{s}}(\mathrm{C}-\mathrm{N}-\mathrm{C})\right]\right.$ \\
\hline $2016 \mathrm{~m}$ & $\approx 1975=1030+945:\left[v(\mathrm{C}-\mathrm{C})+\delta(\mathrm{NH})_{\mathrm{rok}} / v(\mathrm{C}-\mathrm{N})\right]$ \\
\hline $1965 \mathrm{w}$ &
\end{tabular}

\section{Conclusions}

The single $\mathrm{X}$-Ray characterization showed that the $\mathrm{NH}_{3}\left(\mathrm{CH}_{2}\right)_{3} \mathrm{NH}_{3} \mathrm{SiF}_{6}$ compound crystallized in the monoclinic system with the space group $P 2_{1} / c(Z=4)$. The $V / Z$ ratio variation (cell volume/motifs number per cell) versus the $\mathrm{CH}_{2}$ groups' number were compared

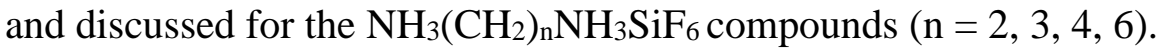

The DSC measurements recorded in heating and cooling $\left(35-245^{\circ} \mathrm{C}\right)$ showed that the unstable title compound undergoes a decomposition process above $30^{\circ} \mathrm{C}$. This thermal behavior is well checked and verified by TGA-dTGA analyses.

The number and symmetry of the IR and Raman active modes of $\mathrm{NH}_{3}\left(\mathrm{CH}_{2}\right)_{3} \mathrm{NH}_{3} \mathrm{SiF}_{6}$ were determined by the factor group analysis to support the vibrational spectra interpretation. Splitting bands observed in the spectra are caused by the site effects on the degenerate internal modes of $\mathrm{SiF}_{6}{ }^{2-}$ anions due to lower symmetry in the crystal structure from $\mathrm{O}_{\mathrm{h}}$ to $\mathrm{C}_{\mathrm{i}}$. The ${ }^{+} \mathrm{NH}_{3}\left(\mathrm{CH}_{2}\right)_{3} \mathrm{NH}_{3}{ }^{+}$cations are considered in the $\mathrm{C}_{1}(4)$ symmetry sites. The Infrared analysis highlights the presence of hydrogen bonding in this compound.

\section{Funding}

This research received no external funding.

\section{Acknowledgments}

This research has no acknowledgment.

\section{Conflicts of Interest}

The authors declare no conflict of interest. 


\section{References}

1. Jeghnou, H.; Ouasri, A.; Elyoubi, M.; Rhandour, A.; Dhamelincourt, M.C.; Dhamelincourt, P.; Mazzah, A. Differential scanning calorimetric and Raman studies of a phase transition in $\left[\mathrm{C}_{3} \mathrm{H}_{7} \mathrm{NH}_{3}\right]_{2} \mathrm{SiF}_{6}$. J. Raman Spectrosc. 2004, 35, 261-265, https://doi.org/10.1002/jrs.1145.

2. Jeghnou, H.; Ouasri, A.; Rhandour, A.; Dhamelincourt, M.C.; Dhamelincourt, P.; Mazzah, A. Structural phase transition in $\left(\mathrm{n}_{-} \mathrm{C}_{4} \mathrm{H}_{9} \mathrm{NH}_{3}\right)_{2} \mathrm{SiF}_{6}$ : DSC and Raman studies. J. Raman Spectrosc. 2003, 34, 126-130, https://doi.org/10.1002/jrs.964.

3. Ouasri, A.; Rhandour, A.; Dhamelincourt, M.C.; Dhamelincourt, P.; Mazzah, A.; Taibi, M. Infrared and Dielectric Studies of $\left[\left(\mathrm{C}_{2} \mathrm{H} 5\right)_{4} \mathrm{~N}_{2} \mathrm{SiF}_{6}\right.$. Phase Transitions 2003, 76, 701-709, https://doi.org/10.1080/0141159021000037240.

4. Ouasri, A.; Rhandour, A.; Dhamelincourt, M.C.; Dhamelincourt, P.; Mazzah, A. Vibrational study of $\left(\mathrm{CH}_{3}\right)_{4} \mathrm{NSbCl}_{6}$ and $\left[\left(\mathrm{CH}_{3}\right)_{4} \mathrm{~N}_{2} \mathrm{SiF}_{6}\right.$. Spectrochimica Acta Part A: Molecular and Biomolecular Spectroscopy 2002, 58, 2779-2788, https://doi.org/10.1016/S1386-1425(02)00019-7.

5. Ouasri, A.; Rhandour, A.; Dhamelincourt, M.C.; Dhamelincourt, P.; Mazzah, A.; Taibi, M. Structural phase transitions in $\left[\left(\mathrm{C}_{2} \mathrm{H} 5\right)_{4} \mathrm{~N}_{2} \mathrm{SiF}_{6}\right.$ : differential scanning calorimetry and Raman studies. J. Raman Spectrosc. 2002, 33, 715-719, https://doi.org/10.1002/jrs.902.

6. Reiß, G.J. Bis(diisopropylammonium) Hexafluorosilicate(IV). Acta Crystallographica Section C 1998, 54, 1489-1491, https://doi.org/10.1107/S010827019800609X.

7. Kosturek, B.; Czapla, Z.; Wb. Structure and Phase Transition of $\left[\left(\mathrm{CH}_{2} \mathrm{OH}\right)_{3} \mathrm{CNH}_{3}\right]_{2} \mathrm{SiF}_{6}$. Z. Naturforsch 2003, 58a, 121-125.

8. Podsiadła, D.; Czupiński, O.; Rospenk, M.; Kosturek, B. Vibrational spectroscopic, optical and thermal properties of a deuterated ferroic crystal, $\left[\left(\mathrm{CH}_{2} \mathrm{OD}\right)_{3} \mathrm{CND}_{3}\right]_{2} \mathrm{SiF}_{6}$ - An experimental and theoretical study. Vib. Spectrosc 2012, 59, 47-58, https://doi.org/10.1016/j.vibspec.2011.12.015.

9. Bozkurt, E.; Kartal, İ.; Karabulut, B. $\gamma$-irradiated $\left[\left(\mathrm{CH}_{3}\right)_{4} \mathrm{~N}_{2} \mathrm{SiF}_{6}\right.$ single crystal investigation by electron paramagnetic resonance technique. J. Mol. Struct. 2007, 834-836, 308-310, https://doi.org/10.1016/j.molstruc.2006.09.034.

10. Gudymenko, O.; Glushakov, V.; Boiko, O. Tetraalkylammonium Fluorosilicates as Precursors for Electrochemical Deposition of Silicon Coatings. Synthesis and Thermal Stability. J. Chem. Chem. Eng. 2015, 9, https://doi..org/10.17265/1934-7375/2015.06.001.

11. Ouasri, A.; Rhandour, A.; Dhamelincourt, M.-C.; Dhamelincourt, P.; Mazzah, A. The infrared and Raman spectra of ethylammonium hexafluorosilicate $\left[\mathrm{C}_{2} \mathrm{H}_{5} \mathrm{NH}_{3}\right]_{2} \mathrm{SiF}_{6}$. Spectrochimica Acta Part A: Molecular and Biomolecular Spectroscopy 2003, 59, 357-362, https://doi.org/10.1016/S1386-1425(02)00165-8.

12. Ouasri, A.; Rhandour, A.; Dhamelincourt, M.-C.; Dhamelincourt, P.; Mazzah, A. Structure and vibrational study of the trimethylammonium hexafluorosilicate $\left[\left(\mathrm{CH}_{3}\right)_{3} \mathrm{NH}\right]_{2} \mathrm{SiF}_{6}$ compound. Spectrochimica Acta Part A: Molecular and Biomolecular Spectroscopy 2003, 59, 851-857, doi:https://doi.org/10.1016/S13861425(02)00231-7.

13. Gelmboldt, V.O.; Kravtsov, V.C.; Fonari, M.S. Ammonium hexafluoridosilicates: Synthesis, structures, properties, applications. J. Fluorine Chem. 2019, 221, 91-102, https://doi.org/10.1016/j.jfluchem.2019.04.005.

14. Anisimov, V.Y.; Shishkin, I.O.; Kravtsov, V.K. Synthesis, Structure, and Anticaries Activity of 2-Amino-4, 6-Dihydroxypyrimidinium Hexafluorosilicate. Pharm. Chem. J. 2018, 52, 606-610.

15. Gelmboldt, V.O.; Anisimov, V.Y.; Shyshkin, I.O.; Fonari, M.S.; Kravtsov, V.C. Synthesis, crystal structures, properties and caries prevention efficiency of 2-, 3-, 4-carboxymethylpyridinium hexafluorosilicates. $J$. Fluorine Chem. 2018, 205, 15-21, https://doi.org/10.1016/j.jfluchem.2017.11.004.

16. Gelmboldt, V.O.; Shyshkin, I.O.; Fonari, M.S.; Kravtsov, V.K. Synthesis, Crysta Structure, and Some Propertie of 4-Hydroxymethylpyridinium Hexafluorosilicate. J. Struct. Chem. 2019, 60, 1150-1155, https://doi.org/10.1134/S0022476619070175.

17. Gelmboldt, V.O.; Shyshkin, I.O.; Anisimov, V.Y.; Fonari, M.S.; Kravtsov, V.C. Bis(3hydroxymethylpyridynium) hexafluorosilicate monohydrate as a new potential anticaries agent: Synthesis, crystal structure and pharmacological properties. J. Fluorine Chem. 2020, 235, 109547, https://doi.org/10.1016/j.jfluchem.2020.109547. 
18. Anisimov, V.Y.; Shyshkin, I.O.; Levitsky, A.P.; Gelmboldt, V.O. Cariesprophylactic and periodontoprotective action of octenidine hexafluorosilicate in rats obtained with cariesogenic ration. Farm. Zh. 2019, 86-95, https://doi.org/10.32352/0367-3057.3.19.10.

19. Gelmboldt, V.; Ognichenko, L.; Shyshkin, I.; Kuz'min, V. QSPR models for water solubility of ammonium hexafluorosilicates: analysis of the effects of hydrogen bonds. Struct. Chem. 2021, 32, 309-319, https://doi.org/10.1007/s11224-020-01652-3.

20. Gelmboldt, V.O.; Lytvynchuk, I.V.; Shyshkin, I.O.; Ognichenko, L.N.; Kuz'min, V.E. Prognosis of biological activity and lipophilicity of some pyridine derivatives as components of anticaries agents. Farm. Zh. 2020, 79-85, https://doi.org/10.32352/0367-3057.2.20.08.

21. Pristupa, B.V.; Shyshkin, I.O.; Rozhkovsky, Y.V.; Gelmboldt, V.O. Antiinflammatory activity of 2-, 3-, 4carboxymethylpyridinium hexafluorosilicates on carrageenan model of inflammation. Farm. Zh. 2019, 8287,https://doi.org/10.32352/0367-3057.4.19.09.

22. Gelmboldt, V.O.; Anisimov, V.Y. Ammonium hexafluorosilicates: a new type of anticaries agents. Farm. Zh. 2018, 48-69, https://doi.org/10.32352/0367-3057.5-6.18.04.

23. Elyoubi, M.; Ouasri, A.; Jeghnou, H.; Rhandour, A.; Dhamelincourt, M.C.; Dhamelincourt, P.; Mazzah, A. Vibrational spectroscopic study of alkylenediammonium hexachlorostannate compounds, $\mathrm{NH}_{3}\left(\mathrm{CH}_{2}\right)_{\mathrm{n}} \mathrm{NH}_{3} \mathrm{SnCl6}$ (n = 3 and 4). J. Raman Spectrosc. 2004, 35, 1056-1062, https://doi.org/10.1002/jrs.1254.

24. Ouasri, A.; Elyoubi, M.S.D.; Guedira, T.; Rhandour, A.; Mhiri, T.; Daoud, A. Synthesis, DTA, IR and raman spectra of penthylenediammonium hexachlorostannate $\mathrm{NH}_{3}\left(\mathrm{CH}_{2}\right)_{5} \mathrm{NH}_{3} \mathrm{SnCl}_{6}$. Spectrochimica Acta Part A: Molecular and Biomolecular Spectroscopy 2001, 57, 2593-2598, https://doi.org/10.1016/S13861425(01)00431-0.

25. Elaoud, Z.; Chaabouni, S.; Daoud, A.; Kamoun, S. Chemical preparation and crystalline structure of ethylendiammonium hexafluorosilicate $\mathrm{NH}_{3}\left(\mathrm{CH}_{2}\right)_{2} \mathrm{NH}_{3} \mathrm{SiF}_{6}$. C. r. acad. sci., Sér. II Méc. phys. chim. astron 1995, 320, 551-555.

26. Ouasri, A.; Rhandour, A.; Saadi, M.; El-Ammari, L. Crystal Structure of butylenediammonium hexafluorosilicate $\mathrm{NH}_{3}\left(\mathrm{CH}_{2}\right)_{4} \mathrm{NH}_{3} \mathrm{SiF}_{6}$. Acta Cryst. 2014, E70, o174, doi:10.1107/S1600536814001068

27. Ouasri, A.; Rhandour, A.; Saadi, M.; El Ammari, L. Hexane-1, 6-diammonium hexafluorosilicate. Acta Crystallogr. Sect. Sect. E: Struct. Rep. Online 2014, 70, 092-093, https://doi.org/10.1107/s1600536813034144.

28. Ouasri, A.; Lambarki, F.; Rhandour, A.; Zahariev, T.K.; Trendafilova, N.; Georgieva, I. Solid state DFT modeling and vibrational characterisation of butylenediammonium and hexylenediammonium hexafluorosilicate, $\mathrm{NH}_{3}\left(\mathrm{CH}_{2}\right)_{\mathrm{n}} \mathrm{NH}_{3} \mathrm{SiF} 6 \quad(\mathrm{n}=4 \quad$ and $\quad 6) . \quad$ Vib. Spectrosc 2017, 88, 83-93, https://doi.org/10.1016/j.vibspec.2016.11.006.

29. Benzekri, Z.; Serrar, H.; Sibous, S.; Boukhris, S.; Ouasri, A.; Rhandour, A.; Souizi, A. Hybrid crystal $\mathrm{NH}_{3}\left(\mathrm{CH}_{2}\right)_{4} \mathrm{NH}_{3} \mathrm{SiF} 6$ as an efficient catalyst for the synthesis of benzoxazoles, benzimidazoles and benzothiazoles under solvent-free conditions. Green Chemistry Letters and Reviews 2016, 9, 223-228, https://doi.org/10.1080/17518253.2016.1242662.

30. Benzekri, Z.; Serrar, H.; Said, B.; Ouasri, A.; Hassikou, A.; Rhandour, A.; Souizi, A. $\mathrm{NH}_{3}\left(\mathrm{CH}_{2}\right)_{6} \mathrm{NH}_{3} \mathrm{SiF}_{6}$ catalyzed highly efficient synthesis of benzimidazoles, benzoxazoles, benzothiazoles, quinoxalines and pyrimidin-2-ones/thiones. French-Ukrainian Journal of Chemistry 2017, 5, 60-71, https://doi.org/10.17721/fujcV5I1P60-71.

31. Ouasri, A.; Elyoubi, M.S.D.; Rhandour, A.; Georgieva, I.; Zahariev, T.; Trendafilova, N.; Roussel, P. X-ray structures, solid state periodic DFT modeling and vibrational study of alkylenediammonium hexachlorostannates compounds $\mathrm{NH}_{3}\left(\mathrm{CH}_{2}\right)_{n} \mathrm{NH}_{3} \mathrm{SnCl}_{6}(\mathrm{n}=3,4$, 5). J. Mol. Struct. 2019, 1177, 55-67, https://doi.org/10.1016/j.molstruc.2018.09.040.

32. El Adel, L.; Ouasri, A.; Rhandour, A.; Saadi, M.; El Ammari, L.; Hajji, L. Crystal structure, DSC, TGA and electrical studies of Bis (1,12-dodecamethylenediammonium hexachlorobismuthate chloride dihydrate $\begin{array}{llllll}\left(\mathrm{C}_{12} \mathrm{H}_{30} \mathrm{~N}_{2}\right){ }_{2} \mathrm{BiCl}_{6} . \mathrm{Cl} \cdot 2 \mathrm{H}_{2} \mathrm{O} . \quad \text { J. } & \text { Mol. } & \text { Struct. } & \mathbf{2 0 2 0}, & 1207, & 127806,\end{array}$ https://doi.org/10.1016/j.molstruc.2020.127806.

33. Jeghnou, H.; Ouasri, A.; Rhandour, A.; Dhamelincourt, M.C.; Dhamelincourt, P.; Mazzah, A.; Roussel, P. Structural phase transition in $\left[\mathrm{NH}_{3}\left(\mathrm{CH}_{2}\right)_{5} \mathrm{NH}_{3}\right] \mathrm{BiCl}_{5}$ : thermal and vibrational studies. J. Raman Spectrosc. 2005, 36, 1023-1028, https://doi.org/10.1002/jrs.1400. 
34. Mousdis, G.A.; Papavassiliou, G.C.; Terzis, A.; Raptopoulou, C.P. Notizen: Preparation, Structures and Optical Properties of $\left[\mathrm{H}_{3} \mathrm{~N}\left(\mathrm{CH}_{2}\right)_{6} \mathrm{NH}_{3}\right] \mathrm{BiX} 5(\mathrm{X}=\mathrm{I}, \mathrm{Cl})$ and $\left[\mathrm{H}_{3} \mathrm{~N}\left(\mathrm{CH}_{2}\right)_{6} \mathrm{NH}_{3}\right] \mathrm{SbX}_{5}(\mathrm{X}=\mathrm{I}, \mathrm{Br})$. Zeitschrift für Naturforschung $\quad B \quad \mathbf{1 9 9 8}, \quad 53, \quad 927-932, \quad$ https://doi.org/10.1515/znb-1998-0825. 29. Ouasri, A.; Rhandour, A.; Saadi, M.; El Ammari, L. catena-Poly [heptylenediammonium [[tetrachloridobismuthate (III)]- $\mu$-chlorido]]. Acta Crystallogr. Sect. Sect. E: Struct. Rep. Online 2013, 69, m437, doi: 10.1107/S1600536813018102

35. Ouasri, A.; Jeghnou, H.; Rhandour, A.; Roussel, P. Structures and phases transition in hexylenediammonium pentachlorobismuthate (III) $\left[\mathrm{NH}_{3}\left(\mathrm{CH}_{2}\right)_{6} \mathrm{NH}_{3}\right] \mathrm{BiCl}_{5}$ crystal. J. Solid State Chem. 2013, 200, 22-29, https://doi.org/10.1016/j.jssc.2013.01.002.

36. Ouasri, A.; Jeghnou, H.; Rhandour, A.; Mazzah, A.; Roussel, P. X-ray, thermal and vibrational studies of two structural phases transition in hexylenediammonium pentachlorobismuthate (III) $\left[\mathrm{NH}_{3}\left(\mathrm{CH}_{2}\right)_{6} \mathrm{NH}_{3}\right] \mathrm{BiCl}_{5} . J$. Mol. Struct. 2012, 1028, 79-87, https://doi.org/10.1016/j.molstruc.2012.05.061.

37. Rhandour, A.; Ouasri, A.; Roussel, P.; Mazzah, A. Crystal structure and vibrational studies of butylenediammonium pentachlorobismuthate (III) hydrate $\left[\mathrm{NH}_{3}\left(\mathrm{CH}_{2}\right)_{4} \mathrm{NH}_{3}\right] \mathrm{BiCl}_{5} \cdot \mathrm{H}_{2} \mathrm{O}$. J. Mol. Struct. 2011, 990, 95-101, https://doi.org/10.1016/j.molstruc.2011.01.022.

38. Ouasri, A.; Jeghnou, H.; Rhandour, A.; Dhamelincourt, M.-C ; Dhamelincourt, P. ; Mazzah, A. ; Roussel, P. Thermal and vibrational studies of propylenediammonium hexachllrobismuthate dihydrate $\left[\mathrm{NH}_{3}\left(\mathrm{CH}_{2}\right)_{3} \mathrm{NH}_{3}\right]_{3}\left(\mathrm{BiCl}_{6}\right)_{2} 2 \mathrm{H}_{2} \mathrm{O}, \quad J . \quad$ Raman spectroscopy, 2005, 36, 791-796. https://doi.org/10.1002/jrs.1365

39. Benzekri, Z.; Sibous, S.; Serrar, H.; Ouasri, A.; Boukhris, S.; Ghailane, R.; Rhandour, A.; Souizi, A. $\mathrm{NH}_{3}\left(\mathrm{CH}_{2}\right)_{5} \mathrm{NH}_{3} \mathrm{BiCl}_{5}$ as a new hybrid and efficient catalyst for the synthesis of 1(benzothiazolylamino)methyl-2-naphthol derivatives under solvent-free conditions. J. Mol. Struct. 2020, 1202, 127308, https://doi.org/10.1016/j.molstruc.2019.127308.

40. Benzekri, Z.; Sibous, S.; Serrar, H.; Ouasri, A.; Boukhris, S.; Rhandour, A.; Souizi, A. $\mathrm{NH}_{3}\left(\mathrm{CH}_{2}\right)_{5} \mathrm{NH}_{3} \mathrm{BiCl}_{5}$ : an efficient and recyclable catalyst for the synthesis of benzoxazole, benzimidazole and benzothiazole heterocycles. Journal of the Iranian Chemical Society 2018, 15, 2781-2787, https://doi.org/10.1007/s13738018-1465-1.

41. Gantar, D.; Rahten, A. Synthesis and characterization of $\left(\mathrm{N}_{2} \mathrm{H}_{5}\right)_{2} \mathrm{SiF}_{6}$ and thermal analysis of $\left(\mathrm{N}_{2} \mathrm{H}_{5}\right)_{2} \mathrm{SiF}_{6}$ and $\mathrm{N}_{2} \mathrm{H}_{6} \mathrm{SiF}_{6}$. Thermochim. Acta 1986, 108, 149-155, https://doi.org/10.1016/0040-6031(86)85086-9.

42. Arianpour, F.; Arianpour, A.Ç.; Aali, B. Characterization and Properties of Sodium Hexa-Fluorosilicate and its Potential Application in the Production of Sodium Fluoride. Silicon 2020, https://doi.org/10.1007/s12633020-00755-0.

43. Healy, C.; Harvey-Reid, N.C.; Howard, B.I.; Kruger, P.E. Thermal decomposition of hybrid ultramicroporous materials (HUMs). Dalton Transactions 2020, 49, 17433-17439, https://doi.org/10.1039/D0DT03852K.

44. Anastassopoulou, J.D.; Berjot, M.; Marx, J.; Paleos, C.M.; Theophanides, T.; Alix, A.J.P. Raman spectra and conformational analysis of long-methylene-chain-diamine-copper complexes. J. Mol. Struct. 1997, 415, 225237, https://doi.org/10.1016/S0022-2860(97)00103-8.

45. Dhouib, I.; Ouasri, A.; Guionneau, P.; Pechev, S.; Elaoud, Z. Synthesis, molecular structure, vibrational studies, optical properties and electrical conduction mechanism of the new hybrid compound based on selenate. Journal of Saudi Chemical Society 2020, 24, 996-1009, https://doi.org/10.1016/j.jscs.2020.10.007.

46. Dhouib, I.; Ouasri, A.; Elaoud, Z. Disordered structures, vibrational spectroscopy, thermal behavior, and electrical properties of two new tetrachlorometallates complexes $\left[\left(\mathrm{CH}_{3} \mathrm{CH}_{2} \mathrm{CH}_{2}\right)_{4} \mathrm{~N}\right]_{2} \mathrm{MIICl}_{4}$ with $\mathrm{MII}=\mathrm{Co}$ and Mn. Journal of Saudi Chemical Society 2020, 24, 567-583, https://doi.org/10.1016/j.jscs.2020.06.001. 